
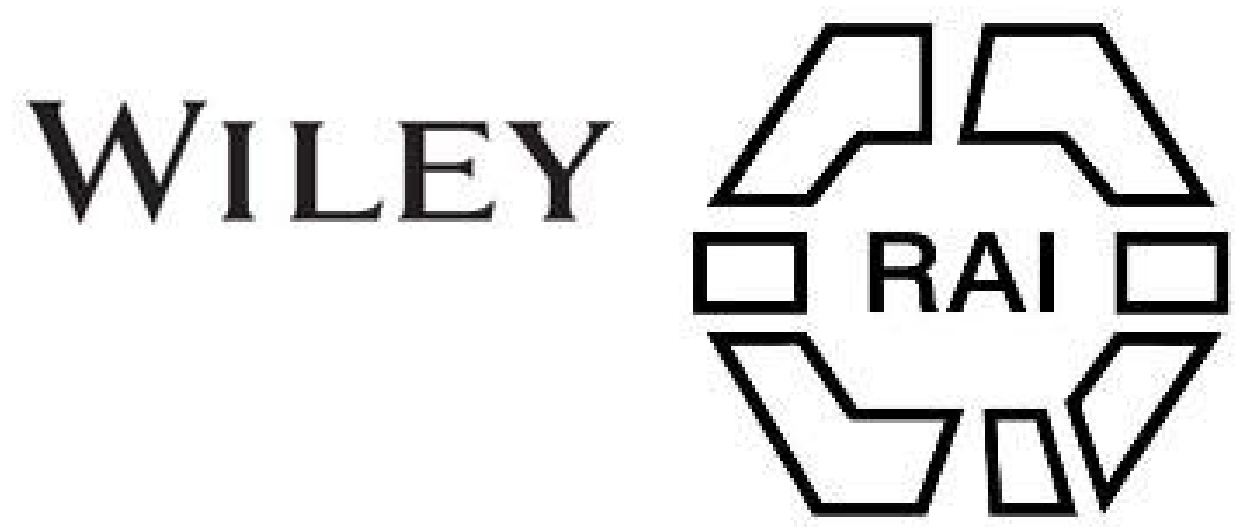

\title{
21. Megalithic Monuments in Gloucestershire
}

\author{
Author(s): A. L. Lewis
}

Source: Man, Vol. 12 (1912), pp. 40-41

Published by: Royal Anthropological Institute of Great Britain and Ireland

Stable URL: http://www.jstor.org/stable/2788383

Accessed: 26-06-2016 04:13 UTC

Your use of the JSTOR archive indicates your acceptance of the Terms \& Conditions of Use, available at

http://about.jstor.org/terms

JSTOR is a not-for-profit service that helps scholars, researchers, and students discover, use, and build upon a wide range of content in a trusted digital archive. We use information technology and tools to increase productivity and facilitate new forms of scholarship. For more information about JSTOR, please contact support@jstor.org.

Wiley, Royal Anthropological Institute of Great Britain and Ireland are collaborating with JSTOR to digitize, preserve and extend access to Man 
With regard to cousins, supposing a man has two daughters and each has a family, the children do not call each other cousins, but brothers and sisters. If, however, a man has a son and a daughter, and they have families, they call each other cousin.

If a woman is enceinte the old women gather together with the woman in the middle. The old women dance and tell her she must be faithful to her husband or she will die when the bahy is born. They also instruct her in what she must eat. She must not eat :-(1) hippopotamus, or the child will have teeth like that animal ; (2) pig, or the baby will be diseased; (3) eggs, or the baby will have no hair : (5) certain fruits, or the baby will have wounds on its thighs.

The husband receives similar instructions from his uncle and friends, to be faithful to his wife or she will die, \&c.

When the birth is expected the old women again gather round the bride and tell her to disclose the names of men she has been with or she will die. If the girl has been unfaithful she will usually give the names, but if she does not she dies. This the natives considered always happened.

The man is also persuaded to give the names of women, if he does not, his wife dies.

When one of them confesses, the child is born.

But if both refuse, recourse is had to the bone-thrower to find out which is guilty. If he cannot find out he asks if the parents of the husband or wife ever had any quarrel concerning the marriage, whether the couple themselves ever quarrelled, or whether the parents of one quarrelled with the parents of the other, If either of these cases is admitted the guilty ones are ordered by the bone-thrower to go and make offerings to the spirits of their grandmother. If after this the baby still remains unborn both parents consult another bone-thrower. Sometimes one bone-thrower reconumends one thing and the other recommends something else, and the parents do not know what to do and can only wait until the baby is born or the mother dies. If the baby is born and the mother lives the husband and parents sing, and the husband with his weapon leaps and imitates fighting. Should the woman die the husband is blamed and has to pay.

H. W. GARBUTT.

\section{England : Archæology.}

Lewis.

\section{Megalithic Monuments in Gloucestershire. By A. L. Lewis.}

The Longstone at Minchinhampton, Gloucestershire, is $7 \frac{1}{2}$ feet high, 5 to

6 feet wide, and 15 inches thick, and has several natural holes in it, through one of which children were formerly passed to cure them of measles or whooping cough. (This, I may say, was also done at the dolmen of Trie Château in the Oise.) This stone was said by Rudder, in his Gloucestershire (1799), to have stood on the top of a tumulus or barrow, but $I$ do not think that it could have done so ; the ground round it is now level, and the stone would have been upset in removing the barrow, if any had existed, and would not have been set up again. Dr. Thurnam said the barrow was "scarcely visible" when he visited the spot in 1860 . It probably required the eye of faith to discern any traces of it at all. Twelve yards slightly south of west from the standing stone is a fallen one ( $4 \frac{1}{2}$ feet by $2 \frac{1}{2}$ by 1$)$, built into a dry stone wall, which may also contain the fragments of other stones, possible even of a whole circle. Within a mile to the south of these there is, however, a stone 5 or 6 feet high called the "Tingle Stone," which does stand on a barrow.

About three miles south-east from this stone is the Rodmarten chambered tumulus, and five or six miles west is the chambered barrow at Uley, both of which are treated of at considerable length in Dr. Thurnam's great paper on "Long Barrows" (Archeologia, Vol. 42). Concerning the Uley barrow he says it was explored in 1821, when 
two dolichocephalic skulls were found and preserved in the museum of Guy's Hospital with a memorandum, unpublished, but it had been ransacked before that time. The

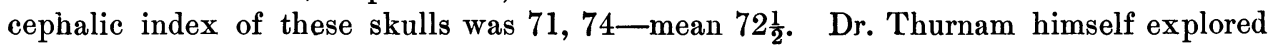
the barrow in 1854 and published an illustrated report in the Archreological Journal, XI, 315 (1854). He found at that time the remains of fifteen skeletons, and eight or nine skulls, none of which had been burnt. Some of the skulls appeared to have been cleft in a manner suggestive of a violent death;; three or four of them were sufficiently perfect to show great length and thickness. Flint flakes were found, which must have been brought from some site many miles away; and two axes, one of flint and one of hard green stone, were found close to the tumulus, and are preserved with the two skulls in the museum of Guy's Hospital. "Above one of the side chambers " and within a foot of the surface of the mound was a skeleton, lying north-east " and south-west, which, from three third brass coins of the three sons of Constantine " the Great deposited with it, appeared to belong to the Roman period" (Dr. Thurnam in Archreologia, XLII, 235). W. C. Borlase (Dolmens of Ireland, p. 974) says : "Roman remains were found in one of the side chambers, and, since among them " was a lachrymatory, the idea presents itself that the cultus of the dead and the " devotions paid to them at this sepulchre had not died out in the age to which " such relics belong." That was a favourite idea with Borlase, and one to which I see no great reason to object, but in the case of Uley it may well have happened that if any Roman objects were really found in the side chamber they had dropped into it from the secondary interment above it. Thurnam, noreover, speaks only of a "small vessel described as resembling a Roman lachrymatory" (Archaological Journal, XI, 321).

The barrow itself, locally called "Hetty Pegler's 'Tump," is 120 feet long, 85 feet broad, and 10 feet high ; the gallery is 23 feet long, divided into three compartments, 10 feet, 9 feet, and 4 feet long respectively; near the entrance it is 5 feet wide, but only 3 feet at the inner end, and it is nowhere more than 5 feet high. At each side of the gallery are two small chambers about 6 feet by 4 feet; two of these have either fallen in or were destroyed when the tumulus was accidentally broken into in 1820 , or perhaps even before that date. The walls of the gallery and chambers are partly of slabs and partly of small dry masonry, and the roof is formed of slabs. There appears to have been a peculiar arrangement of dry stone walling in the body of the tumulus. The figure of the stone axe which is carved on some of the French dolmens does not appear at Uley, but the barrow itself is very much in the shape of an axe; that, however, is probably only an accidental coincidence.

\section{A. L. LEWIS.}

Africa, East.

\section{A'Kikuyu Fairy Tales (Rogano). By Captain W. E. H. Barrett.}

The Six Warriors who Travelled to the Home of the Sun.

Barrett.

In a certain tribe of the A'Kikuyu there were six warriors, all renowned far and wide for their power of endurance and their bravery. These men were continually competing against one another, and each thought that he was superior to the rest. One day they arranged among themselves to make a journey to where the sun lived, and to see him in his own abode. Accordingly, having said good-bye to their relations they started off, each taking with him a bullock for food. 'The first day they travelled a long distance, and in the evening they camped, lit large fires, and killed one bullock, which they ate.

They travelled in the direction of the sun for five days, and each evening they ate one of their bullocks. Towards the evening of the sixth day they came to a vast expanse of water, lying in front of them, and were unable to proceed any 